This item was submitted to Loughborough's Research Repository by the author.

Items in Figshare are protected by copyright, with all rights reserved, unless otherwise indicated.

\title{
Urbanism and geopolitics: the missing links [Editorial]
}

PLEASE CITE THE PUBLISHED VERSION

https://doi.org/10.1016/j.polgeo.2018.10.006

PUBLISHER

(c) Elsevier

VERSION

AM (Accepted Manuscript)

PUBLISHER STATEMENT

This paper was accepted for publication in the journal Political Geography and the definitive published version is available at https://doi.org/10.1016/j.polgeo.2018.10.006

\section{LICENCE}

CC BY-NC-ND 4.0

\section{REPOSITORY RECORD}

Antonsich, Marco, and Michael Hoyler. 2018. "Urbanism and Geopolitics: The Missing Links [editorial]". figshare. https://hdl.handle.net/2134/35426. 
Forthcoming in Political Geography 2018

\title{
Urbanism and geopolitics: the missing links
}

\author{
Marco Antonsich and Michael Hoyler
}

Loughborough University

What are the links between urbanism and geopolitics? Etymologically, both concepts are rooted in the same geographical unit, the Latin urbs and the Greek polis. Yet, despite this shared geography there have been very few studies which have looked into the conceptual links between these two spatial disciplines. Maybe the closest attempt to link urbanism and geopolitics is the body of scholarship which goes under the name of urban geopolitics. Particularly over the last decade, scholars working with and within this notion have tried to bridge the disciplines of political geography, geopolitics, urban studies, planning and architecture in a variety of ways (Fregonese 2012). As Rokem and Fregonese explain in their introduction to a joint intervention on the topic (Rokem et al. 2017), urban geopolitics stems from two main strands of research: the militarization of urban space, with cities becoming the main warfare targets in a deliberate politics of urbicide (Graham 2004; Fregonese 2009; Abujidi 2014); and research on urban conflicts, particularly in ethno-nationally contested cities where the role of planning becomes even more evident in material practices of inclusion and exclusion of communities (Rokem and Boano 2018).

As insightful as this literature has been, the links between urbanism and geopolitics continue however to remain largely unaddressed. This is because urban geopolitics does not seem to be particularly interested in the notion of urbanism, but principally hones in on the urban as a scalar dimension which complements the traditional geopolitical focus on the state. Similarly, within this scholarship, geopolitics is not understood as a formal spatial reasoning (Ó Tuathail and Agnew 1992), but as a synonym of violent conflict - geopolitics as a condition of ongoing violence rather than a b-ordering disciplinary gaze upon the world.

In this editorial, we would like to attend more closely to the discursive logic behind both disciplines as a way to invite colleagues to explore the epistemological and genealogical connections between urbanism and geopolitics. As a starting point we focus on a map (Figure 1), published in 1933 by the French review Prélude, the organ of the Comité central d'action régionale et syndicaliste - a corporatist, anticapitalist and antidemocratic movement which, despite declaring itself beyond left and right, openly sympathized with Fascism (Boyer 2003; 
Richards 2003). What matters here is that one of the key figures of the small editorial board of Prélude was the most renowned urbanist and architect of the $20^{\text {th }}$ century: Charles-Édouard Jeanneret aka Le Corbusier (McLeod 1985).

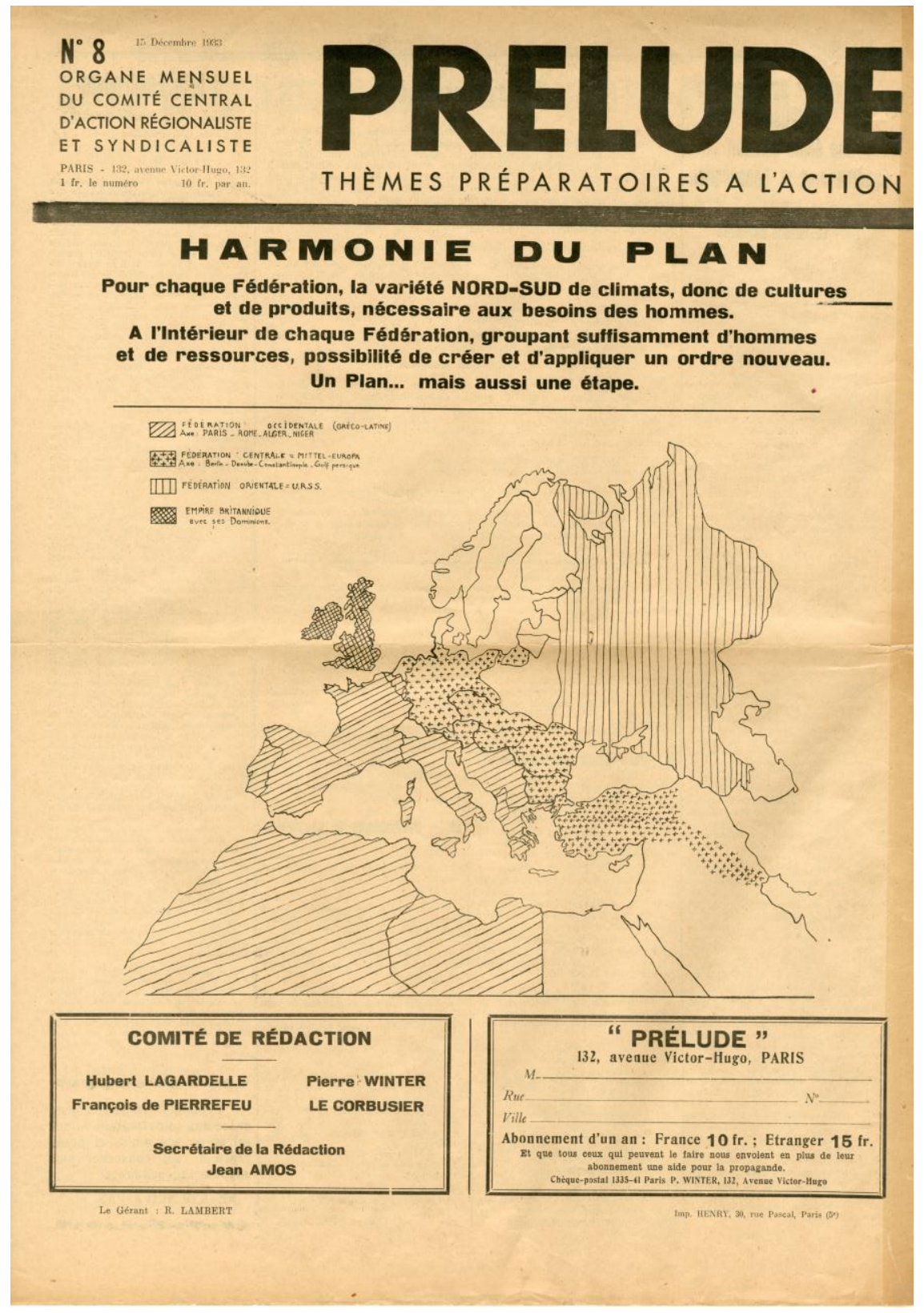

From a geopolitical point of view, the map is not particularly original. It shows a Europe divided between three main blocs, organized longitudinally to include a variety of climates and agricultural products, exactly like the autarkic panregions theorized a few years earlier by German and Italian geopoliticians ( O'Loughlin and Van Der Wusten 1990; Antonsich 1997). The boundaries of these blocs are obviously different, as Prélude aimed to offer a leading role to France which the German-Italian idea of Eurafrica instead denied. The map also presents 
various blank spots, with the Nordic countries, the Baltic States and Poland left without any geopolitical role or affiliation. Cartographically the map is also not very original, as it lacks the dynamic elements (e.g. geometric shapes which represent military and economic forces) introduced by both German and Italian geopolitics (Boria 2008).

What is instead interesting is the key idea which underlines the map and gives its title: Harmonie du Plan (Harmony of Plan). Le Corbusier and colleagues here use a tool adopted from urbanism, the plan, to present a geopolitical view of Europe. The plan is a way of shaping and ordering space according to an organic or harmonic vision. In this sense, it clearly resonates with geopolitics which, in its classic formulations, is similarly driven by a teleologically ordering vision (Ó Tuathail 1994). The scale is different however: classic geopolitics looks beyond the state; modernist urbanism looks within the state. But given the same underlining spatial logic, it is not surprising to see Le Corbusier and colleagues scale up their plan and offer a 'new order' for Europe.

Looking closely at Le Corbusier's urbanism, the similarities with classic geopolitics are even more pronounced. Ideologically, both Le Corbusier and key authors of the classic geopolitical tradition, like Ratzel, Kjellén, Mahan, Mackinder and Haushofer, shared the same form of conservatism: anti-liberal, often anti-democratic, with a clear preference for forms of oligarchic or authoritarian regimes (Parker 1985). Le Corbusier had been an open admirer of Mussolini and with the Fascist doctrine shared the goal of not only reordering space, but also society: ordre nouveau [new order] and homme nouveau [new man] were two important objectives of Le Corbusier's plan ( McLeod 1985; Pinder 2005).

Epistemologically, the points of contacts between classic geopolitics and Le Corbusier's urbanism are even more intriguing. In a compelling analysis of classical geopolitical thought, Ó Tuathail (1996) aptly showed how the validity of geopolitical reasoning relies on a metaphysical authority, the Logos, which is considered external to the author and their geopolitical theories. This logocentrism is possible because classic geopolitics relies on the Cartesian separation between subject and object, so the former positions itself outside the world, offering the illusion that the geopolitical vision is not the product of a politically, culturally, economically and socially located subject but a sort of 'view from nowhere' (Agnew 1998). Similarly, Le Corbusier attributed this metaphysical authority to the plan:

"The despot is not a man. The despot is the Plan. The correct, realistic, exact plan, the one that will provide your solution once the problem has been posited clearly, in its entirety, in its indispensable harmony [...]. And this plan is your despot: a tyrant, a tribune of the people. Without other help, it will plead its cause, reply to objections, overcome the opposition of private interest, thrust aside outworn customs, rescind 
outmoded regulations, and create its own authority. The authority will follow the plan, not precede it." (Corbusier 1967 (1933): 154).

The Plan has its own life, but the planner is the only figure that can master its inner spatial logic, as much as the geopolitician is the only one who can decipher the geopolitical laws which govern the world.

Given these epistemological tenets, it is not surprising that the same geographical determinism which informed classic geopolitics was also at work in Le Corbusier, whose urbanist conceptions appealed to natural principles and laws (Pinder 2005). In the case of the map in Figure 1, it is interesting to note how it was justified not on the basis of diplomatic politics, considered too ephemeral, but on "geographical, ethnographical and demographical needs [nécessités]", which made "this [...] the only possible Plan to organize Europe and to organize the Peace" (J.A. 1933: 1).

The similarities between urbanism and geopolitics are not only confined within the case of Prélude and Le Corbusier. In the same period in Italy, the two disciplines were explicitly brought together as two concurrent forms of 'art of government' by Giuseppe Bottai, the Minister of Education in Mussolini's government (Ernesti 1988). In his vision for a social and economic reorganization of Italy, the urbanist had to play a key role in reordering the physical spaces of the nation, whereas the geopolitician had to embody the geographical consciousness of the nation in its projection over its boundaries (Antonsich 2009). It comes as no surprise that, in 1937, it was Bottai who opened the Primo Congresso Nazionale di Urbanistica and, two years later, provided essential support for the publication of the first Italian geopolitical journal, Geopolitica (1939-1942) (Antonsich 1992; Atkinson 1995).

In this editorial, we have just scratched the surface of the relationship between urbanism and geopolitics. We have pointed to an epistemological continuum between these two disciplines and their traditional scalar focus. Within this continuum one can certainly identify other projects of spatial ordering which operate along the lines discussed above, such as the cityregional plan of Walter Christaller (1933) which, in the same interwar period, was equally driven by a search for spatial order (Rössler 1989; Taylor et al. 2010; Barnes and Minca 2013). The quest for spatial ordering continues today, cartographically more sophisticated but no less geopolitically infused (Taylor and Hoyler 2000; Dühr 2007). This is evident, for example, in the "geopolitical practice of scaling" (Moisio 2011: 23) characterizing the European Union's spatial planning initiatives (e.g., ESPON), and extends to a plethora of concepts describing twenty-first century (city-)regions and regionalism more generally (Paasi et al. 2018: 14-15), which require critical geopolitical analysis. We hope that this reflection will stimulate colleagues working within the broad remit of urban geopolitics and beyond to undertake a more sustained genealogical study of these links, moving beyond the conflation of geopolitics with a condition 
of permanent conflict and recuperating instead the notion of geopolitics as a way of thinking the world, not dissimilarly from urbanism or other forms and scales of spatial planning.

\section{Acknowledgments}

We are grateful to the Foundation Le Corbusier (Paris) and its library director Arnaud Dercelles for assisting us with the archival research.

\section{References}

Abujidi, N. (2014). Urbicide in Palestine: spaces of oppression and resilience. London: Routledge. Agnew, J. (1998). Geopolitics: Re-visioning world politics. London: Routledge.

Antonsich, M. (1992). La coscienza geografico imperiale del regime fascista: 'Geopolitica' (19391942). Milan: Unpublished Masters thesis, Università Cattolica del Sacro Cuore.

Antonsich, M. (1997). Eurafrica. Dottrina Monroe del fascismo. Limes. Rivista Italiana di Geopolitica (3):261-6.

Antonsich, M. (2009). Geopolitica: The 'geographical and imperial consciousness' of Fascist Italy. Geopolitics 14 (2):256-77.

Atkinson, D.A. (1995). Geopolitics and the geographical imagination in Fascist Italy. Loughborough: Unpublished PhD thesis, Department of Geography, Loughborough University.

Barnes, T.J., \& Minca, C. (2013). Nazi spatial theory: the dark geographies of Carl Schmitt and Walter Christaller. Annals of the Association of American Geographers 103 (3): 669-687.

Boria, E. (2008). Geopolitical maps: A sketch history of a neglected trend in cartography. Geopolitics 13 (2):278-308.

Boyer, M.C. (2003). Aviation and the aerial view: Le Corbusier's spatial transformations in the 1930s and 1940s. Diacritics 33 (3/4):93-116.

Christaller, W. (1933 (1966). Die zentralen Orte in Süddeutschland. Jena: Gustav Fischer Verlag; transl. by C.W. Baskin as Central places in Southern Germany. Englewood Cliffs, NJ: PrenticeHall. 
Corbusier, Le. (1967 (1933). The Radiant City. Gouda: Faber.

Dühr, S. (2007). The visual language of spatial planning: Exploring cartographic representations for spatial planning in Europe. London: Routledge.

Ernesti, G. (ed.) (1988). La costruzione dell'utopia: Architetti e urbanisti nell'Italia fascista. Roma: Edizioni Lavoro.

Fregonese, S. (2009). The urbicide of Beirut? Geopolitics and the built environment in the Lebanese civil war (1975-1976). Political Geography 28 (5):309-18.

Fregonese, S. (2012). Urban geopolitics 8 years on. Hybrid sovereignties, the everyday, and geographies of peace. Geography Compass 6 (5): 290-303.

Graham, S. (2004). Cities, war, and terrorism: Towards an urban geopolitics. Oxford: Blackwell. J.A. (1933). Thèmes à réflexion. Prélude, 8: 1.

McLeod, M.C. 1985. Urbanism and Utopia: Le Corbusier from regional syndicalism to Vichy. Princeton, NJ: Unpublished PhD thesis, School of Architecture, Princeton University.

Moisio, S. (2011). Geographies of Europeanization: The EU's spatial planning as a politics of scale. In Luiza Bialasiewicz (ed.) Europe in the world: EU geopolitics and the making of European space, Farnham: Ashgate, 19-40.

O'Loughlin, J. \& Van Der Wusten, H. (1990). Political geography of panregions. Geographical Review 1:1-20.

Ó Tuathail, G. (1994). (Dis)placing geopolitics: writing on the maps of global politics.

Environment and Planning D: Society and Space 12 (5):525-46.

Ó Tuathail, G. (1996). Critical geopolitics: The politics of writing global space. Minneapolis, MN: University of Minnesota Press.

Ó Tuathail, G. \& John Agnew, J. (1992). Geopolitics and discourse: Practical geopolitical reasoning in American foreign policy." Political Geography 11 (2):190-204.

Paasi, A., Harrison, J., \& Jones, M. (2018). "New consolidated regional geographies." In Anssi Paasi, John Harrison and Martin Jones (eds) Handbook on the Geographies of Regions and Territories, Cheltenham: Edward Elgar, 1-20.

Parker, G. (1985). Western geopolitical thought in the twentieth century. London: Croom Helm. 
Pinder, D. (2005). Visions of the city: utopianism, power and politics in twentieth century urbanism. Edinburgh: Edinburgh University Press.

Richards, S. (2003). Le Corbusier and the concept of self. New Haven: Yale University Press.

Rössler, M. (1989). Applied geography and area research in Nazi society: central place theory and planning, 1933 to 1945. Environment and Planning D: Society and Space 7 (4): 419-431.

Rokem, J. \& Boano, C. (eds) (2018). Urban geopolitics: Rethinking planning in contested cities. London: Routledge.

Rokem, J., Fregonese, S., Ramadan, A., Pascucci, E., Rosen, G., Charney, I., Paasche, T. \& Sidaway, J. (2017). Interventions in urban geopolitics. Political Geography 61:253-62.

Taylor, P.J. \& Hoyler, M. (2000). The spatial order of European cities under conditions of contemporary globalisation. Tijdschrift voor Economische en Sociale Geografie 91 (2):176-189.

Taylor, P.J., Hoyler, M. \& Verbruggen, R. (2010). External urban relational process: introducing central flow theory to complement central place theory. Urban Studies 47 (13):2803-2818. 